\title{
Cystathionine Measurement
}

National Cancer Institute

\section{Source}

National Cancer Institute. Cystathionine Measurement. NCI Thesaurus. Code C147331.

The determination of the amount of cystathionine present in a sample. 